\title{
PAUL AUSTER'S POSTMODERN CHARACTERS: A RELATIVISTIC/REFERENTIAL DICHOTOMY
}

\author{
Jesús Bolaño Quintero \\ Universidad de Cádiz \\ jesus.bolano@uca.es
}

\begin{abstract}
Paul Auster is one of the most widely studied postmodern authors and his novels have been extensively used as paradigmatic examples of the fiction of this movement. In the light of the recent theoretical debate about the passing of postmodernism, it seems fundamental to explore the way in which Auster conceives the nature of this paradigm, the problems it arises and their possible solutions. The aim of this article is to analyse two recurring types of characters from the Austerian universe that represent two great sources of influence on the novelist: Ludwig Wittgenstein's philosophy and the ideas from American transcendentalism.

KEYWORDS: Paul Auster, postmodern fiction, American transcendentalism, Ludwig Wittgenstein, Ralph Waldo Emerson, Henry David Thoreau.
\end{abstract}

\section{LOS PERSONAJES POSTMODERNOS DE PAUL AUSTER: UNA DICOTOMÍA RELATIVISTA/REFERENCIAL}

RESUMEN: Paul Auster es uno de los autores posmodernos más estudiados y sus novelas han sido ampliamente utilizadas como ejemplos paradigmáticos de la ficción de este movimiento. A la luz del reciente debate teórico sobre el paso del posmodernismo, parece fundamental explorar la forma en que Auster concibe la naturaleza de este paradigma, los problemas que plantea y sus posibles soluciones. El objetivo de este artículo es analizar dos tipos recurrentes de personajes del universo austeriano que representan dos grandes fuentes de influencia en el novelista: la filosofia de Ludwig Wittgenstein y las ideas del transcendentalismo estadounidense.

PALABRAS CLAVE: Paul Auster, ficción posmoderna, trascendentalismo estadounidense, Ludwig Wittgenstein, Ralph Waldo Emerson, Henry David Thoreau.

Copyright (C) 2021, Los autores. Este artículo está bajo una licencia de Creative Commons Reconocimiento 4.0 Internacional (CC BY) (http://creativecommons.org/licenses/by/4.0/) 


\title{
LES PERSONNAGES POSTMODERNES DE PAUL AUSTER: UNE DICHOTOMIE RELATIVISTE/RÉFÉRENTIELLE
}

\begin{abstract}
RÉSUMÉ : Paul Auster est l'un des auteurs postmodernes les plus étudiés et ses romans ont été largement utilisés comme exemples paradigmatiques de la fiction de ce mouvement. À la lumière du récent débat théorique sur le disparition du postmodernisme, il semble fondamental d'explorer la manière dont Auster conçoit la nature de ce paradigme, les problèmes qu'il se pose et leurs solutions possibles. L'objectif de cet article est d'analyser deux types récurrents de personnages de l'univers austérien qui représentent deux grandes sources d'influence sur le romancier: la philosophie de Ludwig Wittgenstein et les idées du transcendantalisme américain.
\end{abstract}

MOTS CLÉS : Paul Auster, fiction postmoderne, transcendantalisme américain, Ludwig Wittgenstein, Ralph Waldo Emerson, Henry David Thoreau.

Recibido: 30/12/2020. Aceptado: 21/05/21

\section{Introduction}

One of the many recurring characteristics of Paul Auster's works is the dichotomy with which some of the protagonists are presented. These characters become other than merely tributary echoes of erstwhile literature; they are representations of topical themes and, thus, they are rendered either as victims of the problems arisen from postmodern relativism or as futile harbingers of the interrupted project of modernity. In Auster's novels, these characters are depicted either as Wittgensteinian or transcendentalists in their way of acting. The former try to give meaning to reality through words; the latter, through intuition. This dichotomy corresponds to two ways of engaging with conceptions related to metaphysics that are grounded on two of the main sources of influence on the writer.

Broadly speaking, in the Tractatus Logico-Philosophicus, Wittgenstein ascertains that nothing can be known that cannot be expressed through language and, on the other hand, in Philosophical Investigations, he affirms that, depending on the rules of language games of the community in which they are used, the truths that one community accepts do not have to be 
accepted by others. Thus, there is a multiplicity of incommensurable truths ensnaring the postmodern individual perception of reality. For its part, Emerson's transcendentalism cottons on to exactly the opposite: there are absolute truths that respond to a higher structure with a causal meaning. These absolute truths cannot be known through language - which is a flawed and corrupted manifestation of human reason - but by interacting with nature through intuition.

Auster's exploration of postmodernism through his characters, spanning American literary works from the American and European traditions, forestalls and replicates the metaphysics of the postmodern paradigm. This is certainly related to what Ramón Espejo argues in "Coping with the Postmodern: Paul Auster's New York Trilogy" (2014): "[h]is fiction will undoubtedly be informed by a contemporary sensibility and concerned with current issues and theoretical debates, but also sympathetic with older narrative structures and forms and certainly aware of the literary tradition" (Espejo 2014: 171). In the novelist's works the different personas try to make sense of reality at the centre of a society that has lost faith in Lyotardian grand narratives, a society usually represented by the city of New York. This procedure is passive and devoid of creativity. They try to make their way through a reason based on the use of language, which leads them to utter relativism. In order to recover a stable structure, intuitively, some characters act according to transcendentalist precepts. Neither of these two types manages to achieve a coherent identity within the society in which they reside. Language is flawed and leads them to existentialism, solipsism and nihilism. On the other hand, intuitive action is either frustrated by the character's own environment - in many occasions by a casual event — or it is only possible outside their usual social environment, for which these characters are ostracized and, sometimes, they even die or disappear.

The following parts of this article move on to describe in greater detail this dichotomy in The New York Trilogy, Leviathan, Moon Palace, and The Brooklyn Follies. Even though they are not the only works by Auster in which this dichotomy can be found, they are the novels in which these two types of character are perceived more clearly. In addition, this article does not include novels after The Brooklyn Follies because, while the characteristics described continue to appear in them, there is an evolution in the author's sensibility towards the social topics he addresses, ${ }^{1}$ caused

1. The term "sensibility" is used in this article in the sense that Tim Vermeulen and Robin van den Akker give it in their richly conceived article "Notes on Metamodernism" (2010). 
by the paradigm shift that takes place in American fiction after the terrorist attacks on the Twin Towers. ${ }^{2}$

\section{The New York Trilogy}

In the three stories that make up The New York Trilogy, there are characters that develop Thoreauvian characteristics. In City of Glass, we read the following about Quinn, the protagonist of the story:

Each time he took a walk, he felt as though he were leaving himself behind, and by giving himself up to the movement of the streets, by reducing himself to a seeing eye, he was able to escape the obligation to think, and this, more than anything else, brought him a measure of peace, a salutary emptiness within [...] Motion was of the essence. (Auster 2004a: 4)

Quinn becomes an eye, an essential symbol of Emerson's thought. ${ }^{3}$ At the beginning of the story he is a writer, but he slowly turns into pure intuitive action. Leonor Acosta Bustamante expresses that dichotomy between language and action in this story in "Don Quixote in the American Imagination: The Reappropriation of the Icon in Auster's The City of Glass", by recognizing two types of characters among all Paul Auster's doppelgangers that appear in the story:

In City of Glass the protagonist, Daniel Quinn, is primarily a poet, transformed into a writer of detective fiction under the pen name of William Wilson, transformed again into a real-life detective, by incarnating a seemingly 'real' detective named Paul Auster [...] this complex structure of the protagonist's characterization shows the central theme of the novel: the blurring of reality and fiction built upon the blurring opposition between writers (Daniel Quinn/William Wilson/Paul Auster) and detectives (Daniel Quinn/Max Work/Paul Auster). (2010: 107)

2. In Twenty-First-Century Fiction: A Critical Introduction, Peter Boxall establishes the category "post 9/11 novel", in which he includes Paul Auster - among other authors, such as Jonathan Safran Foer, Don DeLillo, Ian McEwan or Kamila Shamsie.

3. This symbol appears for the first time in Emerson's work in his famous essay Nature: "I become a transparent eye-ball; I am nothing; I see there; the currents of the Universal Being circulate through me; I am part or parcel of God" (1998: 1075). The transparent eyeball represents the ability to perceive all that nature has to offer and to understand it without having to process it with reason through the sieve of language. Being transparent, it does not interfere with nature, with which Emerson intends to merge. 
The result of the transformation becomes clear from chapter twelve. From that chapter on, the story becomes a transcript of Walden (the quintessential implementation of the intuitive action of transcendentalist thinking). The narrative style becomes descriptive, in a very similar fashion to the tone used by Thoreau in his book. Quinn's voluntary withdrawal from society and frugal eating resembles the isolation and diet that the transcendentalist followed at Walden Pond. There are passages that make direct reference to Thoreau's work: the narrator says that, once Quinn retires form society to live in an alley "he began to understand the true nature of solitude" (Auster 2004a: 118), while Thoreau states: "I love to be alone. I never found the companion that was so companionable as solitude" (1998b: 1839). The narrator relates the way Quinn subsists dividing this relation into themes - exactly as in Walden. In the sections, the narrator gives an account of the problems he has to cope with: economy, food and shelter. Quinn, like Thoreau, notices with minute detail the changes in the environment, especially the only part where he can observe nature from where he is: the sky. After his retirement, adapting again to his previous life becomes impossible. By transforming into an intuitive character ("a seeing eye") and leaving words behind-" [h] e felt that his words had been severed from him, that now they were a part of the World at large, as real and specific as a Stone, or a lake or a flower. They no longer had anything to do with him" (2004a: 131) - it is impossible for him to adapt to the world of relative language again.

In Ghosts, the protagonist, Blue, does not try to go beyond empirical data, his conjectures are pure metaphysics, in clear allusion to Wittgenstein. Metaphysics is something not to be discussed, since it cannot be made sense of through language. Nevertheless, Blue seems to be getting deeper and deeper into it at the beginning of the story. The Thoreauvian retreat to which he is subjected gradually makes him more transcendentalist and less Wittgensteinian. He thinks, like the Wittgenstein of the Tractatus, that he can equate action with words, that he can come to understand reality with a discourse based on a referential language. However, as the story advances, Blue begins to doubt the very linguistic framework he has always trusted: "For the first time in his experience of writing reports, he discovers that words do not necessarily work, that it is possible for them to obscure the things they are trying to say" (2004b: 149). While he was able to explain the world in a referential way, Blue did not consider anything that could transcend a reality that made sense to him. The moment words begin to mean something that does not have a unique correlate in reality, Blue starts to suffer the anguish caused by postmodern relativism. He resorts then to intuitive action: he receives a message in the mail that he does not know how to interpret, 
and his reaction to this event is the following: "[a]fter thinking it over for a while, he decides that it makes no difference. One way or another, the key to the case is action" (2004: 170; my emphasis). He decides to make sense of reality intuitively, through action. This change, however, leads him to a future different from the one he had planned, outside society as he knows it.

In The Locked Room the two main characters are two sides of the same coin: Fanshawe and the nameless narrator of the story. The former represents transcendentalist intuitive action and the latter, linguistic reasoning. Even though Fanshawe is a talented writer, he cannot shake off the postmodern problems we have referred to so much. In order to find truth, he leaves home, abandoning his wife Sophie - the name of Auster's daughter in real life — and his son, Ben-Auster's middle name in real life. The Locked Room is a symbolist story. Symbolism is a Romantic device in general and a transcendentalist device in particular; it is one of the ways to achieve the referentiality lost by the corrupt use of language. According to Isaiah Berlin, "Symbolism is central in all Romantic thought: that has always been noticed by all critics of the movement" (2013: 115). In explaining this concept, Berlin asserts that there are two types of symbol. Firstly, conventional symbols, which are related to semiotics, to language-Auster's characters related to language make use of these symbols-. They are signs that have certain meanings because there are rules that establish them (Wittgenstein). The other type of symbol that Berlin talks about is a less conventional one. To illustrate it, he gives the example of the meaning of a flag or a national anthem. He also exemplifies it as follows:

\footnotetext{
Suppose someone asks, 'Would you spell out for me what it is that the Word 'England' stood for in the sentence 'England expects every man to do his duty' when Nelson said it? [...] it does not simply mean a group of persons, with names and addresses known to Nelson [...] It plainly does not mean that, because the whole emotive force of the word 'England' extends over something both vaguer and more profound. (2013: 116-117)
}

Berlin discusses the idea of symbol in Romantic terms as a way of representing something that cannot be represented with conventional symbols, with words. It is a forward impulse of an indescribable action on the part of reality (Berlin 2013: 117), of something that is infinite, while conventional symbols are finite, they have a limited scope. The Romantic symbol would be the way to talk about concepts for which language falls short: "[y]ou seek to convey something which you can convey only by such means as you have at your command, but you know 
that this cannot convey the whole of what you are seeking to convey because this whole is literally infinite" (Berlin 2013: 117). Nonetheless, if something is inexpressible, it seems absurd to keep trying to express it. According to Berlin, for Herder, one of the conditions of the human being is expressionism (2013: 67). Not expressing yourself is equal to not living. For the Romantics, living is doing something; action is the expression of one's nature. However, that nature is one with the universe, which is infinite and in perpetual motion, making it inexpressible. That is, the nature of the individual is nature itself, and this cannot be expressed by conventional means. The only way to form an image that can somehow apprehend that reality is through symbolism. Transcendentalists also adopted symbolism to express what Wittgenstein latter believed that should not be spoken about. Along these lines, Emerson expressed the idea that every event that occurs in nature is a symbol of a spiritual fact and that these symbols are the root of all natural language - which becomes corrupted with the passage of time- . While those pristine words are signs that represent nature, for Emerson, nature is a symbol of the spirit:

1. Words are signs of natural facts.

2. Particular natural facts are symbols of particular spiritual facts.

3. Nature is the symbol of spirit. (1998: 1080)

To reach true knowledge of the spirit, one must first pass through the mediation of words between it and nature; it is a second-hand find. However, nature is a symbol of one's identity, it is a dynamic trope, since it is changing, it flows. These symbols are universally true, since they are not mediated by an interpretation. Understanding the symbolism of nature is the way to get to one's own spirit without having to use language. Through the observation of nature, the individual can observe him/herself, his/her own identity. These actions that Herder talks about are what constitute the symbols of Auster's action characters, who are always frustrated and misunderstood by others who have lost the capacity to interpret those symbols as a consequence of the effects of postmodern linguistic relativism.

In light of all this, and continuing with The Locked Room, the fact that Fanshawe is closer to transcendentalism through intuitive action is reflected in phrases like: "One morning, Sophie continued, she woke up after a difficult night and understood that Fanshawe would not be coming back. It was a sudden, absolute truth, never again to be questioned" (Auster 2004d: 205). The symbolic 
act becomes an absolute truth. At one point, the narrator describes Fanshawe almost as a transcendentalist hero, as one of Emerson's representative men - as opposed to those described by his friend Thomas Carlyle in On Heroes, HeroWorship, and the Heroic in History, fundamentally, because of their universalistic nature- . These representative people are not special by nature, but that they manage to be so through intuition and self-reliance. Auster describes Fanshawe as follows:

Fanshawe was not a bookish child [...] one had the impression there was nothing he did not do well [...] He was the best baseball player, the best student, the best looking of all the boys. Any one of these things would have been enough to give him special status - but together they made him seem heroic, a child who had been touched by the gods. (2004d: 216)

However, after this epic description of his friend, he clarifies the following: "Extraordinary as he was, however, he remained one of us. Fanshawe was not a boy-genius or a prodigy; he did not have any miraculous gift that would have set him apart from the children his own age. He was a perfectly normal child" (2004d: 216). The character is not exceptional because he was born that way; he is an absolutely normal child. Yet he is in harmony with himself because he is precisely that, a normal child, Emerson's ideal of knowledge of the truth. ${ }^{4} \mathrm{~A}$ little later he is described in Thoreauvian terms, as an individual eager to experience life: 'Fanshawe would talk to me about the importance of 'tasting life.' Making things hard for yourself, he said, searching out the unknown" (2004d: 217). Like Thoreau, Fanshawe wants to make the most of life by deliberately dealing with its difficulties. All the characters that are related to intuitive action in The New York Trilogy end emulating Thoreau through their actions. All three leave society and are ostracized or, in Fanshawe's case, die.

\section{Leviathan}

Leviathan is probably the work of Auster where the effects of postmodern relativism are most easily seen and, in the words of Aliki Varvogli, "ostensibly,

4. In Nature, Emerson makes it clear that children have a relationship with language very different from the one that adults have. That fact makes them have a closer relationship with nature. Thus, children are closer to the truth because they speak with a non-mediated language, but with a referential one: "[c]hildren and savages use only nouns or names of things, which they convert into verbs, and apply to analogous mental acts" (1998: 1081). 
Auster's most realistic novel to date" (2001: 141). ${ }^{5}$ As Brendan Martin states in Paul Auster's Postmodernity (2008), "Leviathan is a commentary on the ethos of late twentieth-century America, and the novel can be considered Paul Auster's most overtly political work" (2008: 177). It is because of the political slant that Auster adopts in this novel that it stands out as a representative novel of the zeitgeist of postmodernism. In Leviathan the relationship between the two main characters resembles the one between Fanshawe and the narrator of The Locked Room. In fact, as Varvogli aptly points out,

Benjamin Sachs, the missing protagonist of Leviathan, could be described in the words that the narrator of The Locked Room uses to describe Fanshawe: "he was there for you, and yet at the same time he was inaccessible. You felt there was a secret core in him that could never be penetrated, a mysterious center of hiddenness. To imitate him was somehow to participate in that mystery, but it was also to understand that you could never really know him". (2001: 142)

Peter Aaron, who tells the story in the first person, interprets reality through language and Benjamin Sachs, represents transcendentalist intuitive action. The latter is a brilliant writer who decides to start acting intuitively in order to create his own identity. Obviously, both of them are, once more, Paul Auster's alter egos, which is reflected by their names. ${ }^{6}$ From the beginning of the book, some Thoreauvian characteristics are attributed to Sachs, who follows transcendentalism in many of his acts. At the beginning of the novel we are told that, like Thoreau, Sachs went to jail for an act of civil disobedience, ${ }^{7}$ refusing to go to the Vietnam War: "[i]t was very simple, really. I refused to go into the army when they called me up" (1993: 19). Like Thoreau, he could have avoided going to jail, but, also like Thoreau, he wanted to go to prison to show what he thought on the matter by taking a stand for something he believed was wrong. Peter asks Sachs why he didn't avoid going to jail: "[b]ut why go to jail? There were other choices. Canada, Sweden, even France. Thousands of people took off to those places" (1993: 19), Sachs answers: "Because I am a stubborn son-of-a-bitch, that's why. I didn't want to run away. I felt I had a responsibility to stand up and tell them

5. We need to bear in mind that Varvogli's The World that Is the Book, from which that quote was taken, was published in 2001; we could argue that Auster's most realistic novel to date is Sunset Park.

6. Peter Aaron's initials are the same as Auster's, and Benjamin is Auster's middle name. Paul Benjamin is the alias Auster used for his first novel Squeeze Play.

7. In "Resistance to Civil Government" (1849), Thoreau tells how he spent a night in jail for refusing to pay his taxes, for he believed that they supported slavery and the war with Mexico. 
what I thought. And I couldn't do that unless I was willing to put myself on the line" (1993: 19-20).

In Leviathan, the characters are recurrently looking for an identity. They face the impossibility of being able to conform to a grand-narrative. The effects of capitalism have been devastating and "the notion of selfhood has been relegated to the status of a distant memory, which is associated with a distant and more enlightened era" (Martin 2008: 177). The way to resolve the conflicts created by the modern leviathan which is America, resemble the actual case of Theodore Kaczynski, also known as the Unabomber, an anonymous anarchist terrorist that started a bombing campaign targeting, similarly to what is depicted in Leviathan, some relevant American institutions and personalities. Kaczynski could be seen as a real life Austerian character. A former mathematics professor, he turns to action after going to the woods to live in a cabin near Lincoln, Montana. Exactly as all of Auster's characters of action, Sach's real life inspiration "emulated the stance of Transcendentalists, and advocated a return to nature" (Martin 2008: 187).

\section{Moon Palace}

In Moon Palace, Marco, the main character, admires his uncle Victor, who donates his library to him-1492 books, clearly referring to the discovery of America- Victor is a character of intuitive action, just like Marco's grandfather, Thomas Effing. Marco starts out as a language character. He goes to university and reads the all the books that his uncle gives him. However, he becomes a character of intuitive action as the plot of the novel unravels. At the beginning Marco recounts how his uncle takes care of him after losing his mother when he was eleven years old. He never knew anything about his father. Marco describes Victor as the person he loves the most and, more importantly, as his own great particular Lyotardian narrative to hold on to. He was his only link with something larger than himself, with a meta-story that could make sense of reality, just what Auster characters usually lack.

Father figures are usually absent in the Austerian universe and if they are present, either the families are dysfunctional, as in the case of Fanshawe in The Locked Room, or they do not have a good relationship with their children, although there is a strong bond between them, as in the case of Sachs in Leviathan, or they belong to the group of language characters, who educate their children in the games of postmodernity. Auster himself tells in Report from the Interior 
a personal story about his father which is very similar to one told in Leviathan. In the novel, Sachs, as a child, is greatly disappointed when he learns that his father had not fought in World War II. His friends wore items their parents had brought from the front lines when they played games and told stories about them on the battlefield, while Sachs envied them. In Report from the Interior Auster says that "[1]ike all small boys, you wanted your father to be a hero [...] and your father was excluded from consideration because he hadn't fought in [...] the Second World War" (2013: 33). He tells then how one night his father, not wanting to disappoint him, while Auster was sleeping, leaves military objects on the table of his room that did not really belong to him. What differentiates the story in Leviathan from Report from the Interior is that, in the former, Sachs is very proud of her father because he is a person of integrity. In Report from the Interior, however, Auster recounts his disappointment when his father tells him stories about these objects, when he actually knew the truth: "[a]lthough you said nothing, pretending to be happy with your gifts, you hated your father for lying to you like that. Now, all these years later, you feel only pity" (2013: 34).

Victor is a father figure in Marco's life and, being an action character, he provides him with a structure free of relativism. Little by little, Marco becomes one of those Austerian characters that resemble Thoreau: he isolates himself in his apartment and lives extremely modestly. The following passage from Moon Palace is reminiscent of Thoreau's famous maxim "simplicity, simplicity, simplicity!":

I stopped paying my electricity bills in November [...] For several weeks after that, I experimented with a variety of candles, investigating each brand for its cheapness, luminosity, and long-lastingness [...] and now that the refrigerator had been silenced I felt that I was probably better off without electricity anyway [...] I sought out the hidden advantages that each deprivation produced, and once I learned how to live without a given thing, I dismissed it from my mind for good [...] I marveled at how little I regretted the things that were gone. (2004c: 26)

After this, Marco starts feeling constrained by the rules of language games. He expresses it almost literally when he describes the way to behave when walking through the city streets: "If you play by the rules of this game, people will tend to ignore you" (Auster 2004c: 55). The members of a certain community, in this case New York, act according to the established rules, and everything that has been tacitly agreed within it is taken as acceptable behaviour: "[y]ou must 
not stagger or swoon, you must not clutch the walls, you must not sing, for all forms of spontaneous or involuntary behaviour are sure to elicit stares, caustic remarks, and even an occasional shove or kick in the shins" (2004c: 55). Marco calls this a "rigid protocol of behaviour" (2004c: 55). It suffocates him, just as it suffocates Thoreau, and he seeks to escape into nature or, in Baudrillard's terms, the hyperreal simulacrum that Central Park represents - in Marco's words: "a man-made natural world. This was nature enhanced, so to speak" (2004c: 61) He will live in the park with the essentials when it is not possible for him to continue living in his apartment after having spent all his money: "By contrast, life in Central Park allowed for a much broader range of variables. No one thought twice if you stretched out on the grass and went to sleep in the middle of the day" (2004c: 55).

Marco alludes to Heraclitus in a reference to the movement associated with the analogous precepts of the Romantics, which serves as his declaration of intentions to become a man of intuitive action, democratically equalling Whitman and his universe in perpetual flux:

[c]ausality was no longer the hidden demiurge that ruled the universe: down was up, the last was the first, the end was the beginning. Heraclitus had been resurrected from his dung heap, and what he had to show us was the simplest of truths: reality was a yo-yo, change was the only constant. (2004c: 61)

After this he gets rid of the ballast of causality when he reads a sports review in which chance begins to have more weight in his way of thinking. Marco renounces language in order to live intuitively and makes it crystal clear in a passage reminiscent of Walden: "I understood that I had already spent too much of my life living through words, and if this time was going to have any meaning for me, I would have to live in it as fully as possible, ${ }^{8}$ shunning everything but the here and now, the tangible, the vast sensorium pressing down on my skin" (2004c: 61-62). His grandfather-although at this point in the novel Marco still doesn't know that he is related to him-, Thomas Effing, blind and in a wheelchair, helps him in his search for an identity by bringing him closer to the poetic language of Emerson, which we could compare with the Herderian Ursprache (which is diametrically opposed to Wittgenstein's notion of the human language). Effing's character is repeatedly compared to

8. This brings to mind the following passage from Walden: "I wanted to live deep and suck out all the marrow of life" (1998b: 1816). 
that of a child. The following passage, for example, describes how his caregiver prepares him to eat:

[s] he always came to the table armed with a fresh towel and a bib. The bib would be tied around Effing's neck before the meal began, and the towel would be used for wiping his face in sudden emergencies. In that regard, it was something like sitting down to eat with a small child. Mrs. Hume took on the role of attentive mother with great assurance". (2004c: 111)

Effing, who employs Marco to read him books and take him out for walks in the city, uses and understands language in a unique way, just like Emersonian children. He does not understand their metaphorical or ironic use, thus, for example, he does not understand set phrases well, since they do not make a referential use of language:

"Do you know how to hold your tongue?"

"If it's called for, I suppose I'm as good at being silent as the next man".

"And what man would that be, boy?"

“Any man. It’s a form of expression”. (2004c: 102)

On their first outing, Effing asks him to describe objects he points to with his cane and vehemently reprimands Marco when he makes a non-referential use of language in his descriptions. Effing needs the boy to describe reality as it is, which Marco is not used to:

$[\mathrm{u}]$ ntil then, I had always had a penchant for generalizing, for seeing the similarities between things rather than their differences. Now I was being plunged into a world of particulars, and the struggle to evoke them in words, to summon up the immediate sensual data, presented a challenge I was ill prepared for". (2004c: 117)

Effing wants Marco, like Pavel Shum, an old friend of his, to find "the palpable truth of objects" (2004c: 117). The primal language that Emerson himself considers to have been lost and to be in direct relation to objects in reality is a way of arriving at the truth that cannot be counted on in a postmodern society. In fact, so that Marco can do what he asks of him, Effing teaches him to look at the world as if it was "a process of training myself how to look at the World as if I were discovering it for the first time" (2004c: 118), that is, without 
the mental burden of his historical memory. He teaches him to look at the world as "[a] spiritual exercise" (2004c: 118).

"The world enters us through our eyes, but we cannot make sense of it until it descends into our mouths" (2004c: 118). This Wittgensteinian passage is uttered by Marco when he realizes what Effing is asking of him. "[H]ow great that distance was (from the eyes to the mouth), to understand how far a thing must travel in order to get from the one place to the other" (2004c: 118). Auster's characters (Benjamin Sachs, Fanshawe, Renzo Michaelson) ${ }^{9}$ who have the ability of putting their experience into words have a direct connection between those two places. They make use of the pristine referential Emersonian language. Marco learns to express in this way how he feels about his first descriptions: "Mere shadows flitting across a blurred background" (2004c: 118), which brings us to Platonic philosophy and, by extension, both to Wittgenstein and Emerson. For Wittgenstein, knowing those shadows in the most exact way in which language allows us is the most important thing, not because what is outside the cave is not relevant, but because it is the only thing we can know, since we are constrained by our language. For Emerson, the important thing is outside the cave and he is aware that words constrain us, that is why transcendentalism aspires to transcend the inherited paradigms to which language subjects us.

At the end of the book, Marco, fully turned into pure transcendentalist action, following a very American literary tradition, travels westward through the United States to the Pacific. When he reaches the coast, in his words, what is left is the void in front of him. Through action he has found meaning, but not within a society with rules that can constrain the process that leads to "the palpable truth of objects". In a postmodern context of eternal present, Marco feels a future in a moment of epiphany: "This is where I start, I said to myself, this is where my life begins" (2004c: 298).

\section{The Brooklyn Follies}

In The Brooklyn Follies the relationship between the two main characters, Tom and Nathan, is very similar to that of Fanshawe and the narrator of The Locked Room. In this case, Nathan is a man of words, he has the project of making a postmodern, fragmented and self-referential book, The Book of Human Folly, which is diametrically opposed to the company that he wants to start at

9. Renzo Michaelson is a character in Sunset Park. 
the end of the book, Bios Unlimited. This latter project stems from a near-death experience that helps Nathan put things in perspective after having a moment of epiphany. With Bios Unlimited he tries to bring people closer to other people. It is a project focused on others, on creating a feeling of community. The Book of Human Folly, on the other hand, is a work that arises (literally) from a lapsus linguae and that aims to capture "an account of every blunder, every pratfall, every embarrassment, every idiocy, every foible, and every inane act I had committed during my long and checkered career as a man" (2005: 5) ${ }^{10}$ His plan for the last part of his life is humble but he endows it with a great title (exactly the opposite of his last project), and he intends to write it "in the simplest, clearest language possible" (2005: 5). In the first chapter of Jesús A. González and Stefania Ciocia's The Invention of Illusions (2011), Paolo Simonetti speaks about Nathan - regarding The Book of Human Folly — saying that he reminds of an ancient postmodern writer (2011: 17). The character goes from a postmodern project to a post-postmodern one at the end of the novel. However, this plan is thwarted by the 9/11 attacks. According to Simonetti, The Book of Human Folly "resembles the umpteenth postmodern pastiche" (2011: 18). To justify this, Simonetti offers a fragment from The Brooklyn Follies where Nathan speaks truly like a postmodern author:

I called the project a book, but in fact it wasn't a book at all. Working with yellow legal pads, loose sheets of paper, the backs of envelopes and junk mail form letters for credit cards and home-improvement loans, I was compiling what amounted to a collection of random jottings, a hodgepodge of unrelated anecdotes that I would throw into a cardboard box each time another story was finished. There was little method to my madness. Some of the pieces came to no more than a few lines, and a number of them, in particular the spoonerisms and malapropisms I was so fond of, were just a single phrase. (2011: 6)

Nonetheless, Simonetti explains that Nathan cannot carry out his frivolous project, in exactly the same manner as Auster

could not write the comedy he had in mind when he first conceived Follies. The jokes and circumvolutions of chance- "Call them parallels, call them coincidences"- are considered

10. This book is reminiscent of the "Archivo General del Fracaso" (general archive of failure) that appears in Aire de Dylan (2012), a book by the Spanish writer Enrique Vila-Matas, a personal friend of Auster's whose work is also concerned with characters of language and the impossibility to really build a coherent structure for reality through words. 
by Tom mere "external facts", and so "less important than the inner truth of each man's life" [...] It is difficult (and politically incorrect) to find bizarre links or make witty jokes in the face of events as tragic as the New York attacks, and even postmodernist writers feel less and less compelled to humour or clever linguistic plays while addressing recent history. (2011: 18)

The other character, Tom, leaves the world of academia and begins to work as a taxi driver because "he couldn't persuade himself to believe in the value of doing it [academic research] anymore" (2005: 23). Being lost, "[t]he cab would teach him lessons that couldn't be learned anywhere" (2005: 24). Again, this character is transformed into an imitation of Thoreau; Tom has made New York his own private Walden Pond, where he is going to learn something fundamental that he needs to know about life, something that academia cannot teach him. There is a great correspondence between the following fragment from Walden and Tom's life choice: "I went to the Woods because I wished to live deliberately [...] and see if I could not learn what it had to teach, and not, when I come to die, discover that I had not lived" (1816). Tom escapes from his comfortable second-hand learned precepts to really discover the essence, "the marrow of life" (Thoreau 1998b: 1816). He sets out to live in a Spartan way and even the studio where he lives is described, once again, as something similar to the cabin next to Walden Pond:

He lived in a studio apartment on the corner of Eighth Avenue and Third Street [...] It was a dingy one-closet cell with a metal shower in the bathroom, a pair of windows that looked out on a brick wall, and a pint-sized kitchenette that featured a bar refrigerator and a twoburner gas stove. One bookcase, one chair, one table, and one mattress on the floor. It was the smallest apartment he had ever lived in. (2005: 25)

At the end of The Brooklyn Follies, the 9/11 attacks put an end to the possible dreams of the inhabitants of New York. It also plays a fundamental role in Nathan's plans, as it abruptly interrupts the epiphany that was to divest him of his solipsism. The attacks function as a ghoulish harbinger of what will be the beginning of a new and gloomy era, which will be reflected in the change in sensibility that occurs in Auster's later works, particularly in Sunset Park. 


\section{Conclusion}

This article set out to show how Auster, through the representation of two very different types of characters, manages to expose in his works, on the one hand, the cause of the problems of solipsism, nihilism and existentialism that plague the postmodern individual and, on the other hand, the transcendentalist solution, which is the cause of frustration-since it is impossible to put it into practice due to postmodern relativism. After The Brooklyn Follies, Auster's novels show a change in sensibility as a result of the shock in which Americans - and what it meant for the rest of the world - were left by the attacks of September 11, 2001. However, even though the change is visible in his work, the author continued to use the same postmodern resources that have always been his trademark. His view on the recovery of a mental structure that can create a structure for the individual's reality continued to be very pessimistic. The language/intuition dichotomy exposes the author's intellectual influences. Ultimately Auster seems to be well aware that the solution to the problems caused by the relativism brought about by postmodern language games is a recovery of the unfinished project of modernity - as conceived by Jürgen Habermas in "Modernity versus Postmodernity" - through an implementation of the thought that is at the root of the grand narrative constituted by the Romantic symbol, in Berlin's terms, that is the United States: a failed Romanticism represented by Auster's admired American transcendentalism.

\section{References}

ACOSTA BUSTAMANTE, L. 2010. “Don Quixote in the American Imagination: The Reappropriation of the Icon in Auster's The City of Glass". In Don Quijote y la narrativa posmoderna. Ed. M. Juliá. Cádiz: Servicio de Publicaciones de la Universidad de Cádiz. 101-115.

AUSTER, P. 2004a (1985). City of Glass. In The New York Trilogy. London: Faber \& Faber. 1-133.

AUSTER, P. 2004b (1986). Ghosts. In The New York Trilogy. London: Faber \& Faber. 137-198.

AUSTER, P. 1993. Leviathan. London: Faber \& Faber. AUSTER, P. 2004c (1989). Moon Palace. London: Faber \& Faber.

AUSTER, P. 2013. Report from the Interior. London: Faber \& Faber. AUSTER, P. 2010. Sunset Park. London: Faber \& Faber.

AUSTER, P. 2006 (2005). The Brooklyn Follies. London: Faber \& Faber. 
AUSTER, P. 2004d (1986). The Locked Room. In The New York Trilogy. London: Faber \& Faber. 201-314.

AUSTER, P. 2004e (1987). The New York Trilogy. London: Faber \& Faber.

BENJAMIN, P. 1982. Squeeze Play. New York, NY: Avon Books.

BERLIN, I. 2013 (1999). The Roots of Romanticism. New Jersey, NJ: Princeton University Press.

BOXALL, P. 2013. Twenty-First-Century Fiction: A Critical Introduction. Cambridge: Cambridge University Press.

CARLYLE, T. 1993 (1841). On Heroes, Hero-Worship, and the Heroic in History. Eds. M. K. Goldberg, J. J. Brattin and M. Engel. Oakland, CA: University of California Press.

EMERSON, R. W. 1998 (1836). Nature. In The Norton Anthology of American Literature (2 vols.). Eds. N. Baym et al. New York, NY: Norton. I: 1073-1101. ESPEJO, R. 2014. "Coping with the Postmodern: Paul Auster's New York Trilogy”. Journal of American Studies 48 (01), 147-171. https://doi. org/10.1017/S0021875813000698

HABERMAS, J. 1981. "Modernity Versus Postmodernity". Trans. S. Ben-Habib. New German Critique 22: 3-14.

MARTIN, B. 2008. Paul Auster 's Postmodernity. London \& New York: Routledge. SIMONETTI, P. 2011. "Loss, Ruins, War: Paul Auster's Response to 9/11 and the 'War on Terror'". In The Invention of Illusions: International Perspectives on Paul Auster. Eds. S. Ciocia and J. A. González. Newcastle upon Tyne: Cambridge Scholars Publisher. 13-38.

THOREAU, H. D. 1998a (1849). "Resistance to Civil Government". In The Norton Anthology of American Literature (2 vols.). Eds. N. Baym et al. New York, NY: Norton. I: 1752-1767.

THOREAU, H. D. 1998b (1854). Walden, or Life in the Woods. In The Norton Anthology of American Literature (2 vols.). Eds. N. Baym et al. New York, NY: Norton. I: 1768-1943.

VARVOGLI, A. 2001. The World that Is the Book: Paul Auster's Fiction. Liverpool: Liverpool University Press.

VERMEULEN, T. and VAN DEN AKKER, R. 2010. "Notes on Metamodernism". Journal of Aesthetics \& Culture 2 (0). https://doi.org/10.3402/jac.v2i0.5677 VILA-MATAS, E. 2012. Aire de Dylan. Barcelona: Seix Barral.

WITTGENSTEIN, L. 1986 (1953). Philosophical Investigations. Trans. G. E. M. Anscombe. Oxford: Blackwell.

WITTGENSTEIN, L. 2002 (1922). Tractatus Logico-Philosophicus. Trans. D. F. Pears and B. F. McGuinness. London: Routledge. 